\title{
OPEN LEGISLATIVE DATA: FROM UKRAINIAN PERSPECTIVE
}

\author{
Nadiia Babynska (Virna) ${ }^{1}$
}

\begin{abstract}
Structured, open by default, accessible, timely data are important source for understanding the parliament, engaging citizens to legislation processes, political analysis and prognosis. Data about voting, MPs, finance and legislation-flow in the parliament are vital and having access to the whole bulk of data - is the main source of information for researchers, journalists, think tanks, parliament itself.
\end{abstract}

Parliaments all around the world produce terabytes of information each year. These are voting records, drafts of laws, legislation, amendments, information about plenary session meetings, speeches, videos, photos, financial information etc. Is this information used by parliament, think tanks, other stakeholders? Or is it hidden in the shelf in offices of parliamentarian clerks?

In this article author tries to explain the importance of open legislative data, how they can be used by and for society. Nadiia Babynska describes her path on opening parliament data in Ukraine, failures and successes in this process. Nadiia Babynska shows the initial need of open legislative data for good governance, engagement citizens, transparency and anti-corruption in parliament. She proposes the main steps to make parliament data open.

\section{Legislative openness and open data}

Access to information, openness, transparency, citizens engagement. These are the key features of open society. All these processes could be passive: citizens write requests for public information and state bodies (parliament, government, local authorities) give it, citizens want to attend plenary meetings, visit state bodies, influence on decision making processes and they receive it on the demand. All these processes could be proactive as well.

If state body (legislation, government, municipality) decides to be proactively open it publishes the whole data it produces and gathers (despite of sensitive information, of course). Data are published in machinereadable format, accessible, free for reuse and timely. This is open data.

According to The International Open Data Charter [1] "open data is digital data that is made available with the technical and legal characteristics necessary for it to be freely used, reused, and redistributed by anyone, anytime, anywhere".

Government, parliament, municipality can produce millions of documents and publish it on their portals is not open data format. In this case it makes the work with this information harder and longer. First, researcher or other analyst have to spend hours and days to digitalize all documents

1 Former coordinator of The Open Data Verkhovna Rada portal, www.opendata.rada.gov.ua, virnadiia@gmail.com, Kyiv, Ukraine, Technovation Challenge Ukraine coordinator 
for making it machinereadable data. This means that computer, program can not work with this information directly. It is not only about openness of data. It is about open data as a format.

There are a lot of progress in open data on the governmental level and on the city level as well. There are at least two big global initiatives that measure the open data development (Open Data Barometer [2] and Global Open Data Index [3]). They are focused on government data. There is also the Local Open Data Census [4] developed "to survey and compare the progress made by different cities and local areas in releasing open data".

It is very little interest to legislative data though. This is very strange as the legislative data are crucial for understanding what is going on (laws), will be going on (drafts of laws), who decides the main questions (members of parliament (MP) in the country, how state money are going to be spent (budget development, finance) and what kind of interests MPs have (voting records, speeches etc). Lack of interest to the data that produce parliament which is representing the electorate, making laws, and overseeing the government [5] leads to lack of fundamental information and understanding, tools for explaining parliamentarian processes and logic.

Legislative data are as important as information about the fuel for the car (even if we know everything about its specification, details).

Open legislative data - is an instrument for analyzing parliamentary processes, monitoring MPs and committees, oversight and accountability. Open legislative data products help citizens understand how parliaments work, involve citizens in legislation, explain the law-making logic, develop and increase their political culture.

In 2016 me with my colleague Grygorij Sorochan explored open data in parliaments around the world ("Open Parliament Data: from a trend to a necessity")[6]. The parliaments of Austria, Bosnia and Herzegovina, Brazil, Bulgaria, Chile, Costa Rica, Czech Republic, Denmark, France, Italy, Norway, Paraguay, Russian Federation, Sweden, Switzerland, Ukraine, United Kingdom and Scotland have their own websites or special sites dedicated to open parliament data. Open data portal of British Parliament [7] is one of the best. It contains 34 groups of data sets, and the number is constantly increasing. The portal contains information about electronic petitions, electoral constituencies, agenda, voting results etc.

Open data portal of French Senate [8] contains four large data sets (law-making, amendments, questions and reports), as well as information about MPs and election outcomes.

Sweden Parliament [9] has 200,000 documents available on its portal, dating from 1971. For example, calendar, list of speakers, legislation, information about MPs, voting results, and speeches of MPs.

Norwegian Parliament's open data website [10] contains information about voting, legislation, questions and representatives.

The European Parliament does not have its own open data portal. 51 datasets about the European Parliament are published on the European Union Open Data Portal [11]. There are mostly results of surveys and very little information in machine-readable format on legislation, MEPs etc. 
Open data portals of parliaments should have such kind of functions as raw data download, use of an API (application programming interface), examples of using open data, support, consulting and trainings for users.

Open legislative data are used by parliaments itself as well as parliament monitoring organizations (PMO) for developing different products on the base of open legislative data. For example, The Law Factory / La Fabrique de la Loi [12] in France (tracking the evolution of a legislative initiative), They Work For You in UK, They Vote For You in Australia and Ukraine (gives statistical information per faction or an MP to see whether he is consistent in his choices, who votes contrary to his faction's policy etc.)

There is a lot about open data in the annual report on e-parliament, conducted by InterParliamentary Union. Researchers admit in the World e-parliament report 2016 [13], that "open data heralds a potentially seismic shift in the relationship between parliament and citizens. No longer is the citizen solely a recipient of broadcast information, whether from parliament, members or the media. Today many are able to participate because of access to the information, documents and data that parliaments generate. Making documentation and content more available is a critical trend too, whether this is through web-based technologies or through open data".

\section{Parliaments that Parliaments that would like support receive support}

\begin{tabular}{|c|c|c|}
\hline $51 \%$ & Application development & $18 \%$ \\
\hline$\overline{51 \%}$ & Document standards & $17 \%$ \\
\hline $52 \%$ & Citizen engagement & $15 \%$ \\
\hline $53 \%$ & Open data & $12 \%$ \\
\hline $49 \%$ & Social media & $8 \%$ \\
\hline
\end{tabular}

\section{Open legislative data in Ukraine}

Parliamentary openness in Ukraine became the public commitment of Verkhovna Rada (Ukrainian Parliament) on February 2016. Ukrainian parliament has joined to the global open parliament movement by endorsing the Declaration on Parliamentary Openness [14]. The National Action Plan [15] on the implementation of the main principles was developed and adopted by the order of the Chairman. Verkhovna Rada took 21 commitments to become more open and transparent, One of the main chapters of Declaration is "Technology and Innovation". According to this chapter parliament data should be open by default and the Open data portal should be developed and sustained by the ICT department of Administrative office of Parliament ("Providing public access to data sets in the form of Open Data on Parliament's web-resources").

In the National Action Plan is written, that "the Resolution of the Cabinet of Ministers of Ukraine No. 835 of 21 October 2015 "On approval of the Regulation on Data Sets to be Published in the Form of Open Data" establishes the obligation of the Ukrainian Parliament to provide public access and timely updates of data sets on its official web-resources within six months. Thus, by April 2016 
the Administrative Office of the Ukrainian Parliament must publish its datasets in formats provided by the Regulation:

- Guide of companies, enterprises (institutions) and organisations of the administrator and its lower organisations, including their phone numbers and addresses

- $\quad$ Staff schedule of the administrator

- $\quad$ Report on use of budget funds (for administrators using the budget funds), particularly, for individual budget programmes

- Standards approved by the administrator of information

- $\quad$ Lists of national standards, which, in the event of their voluntary application, present evidence of compliance of products with the requirements of technical regulations

- $\quad$ Reports on inspections and other control measures undertaken by the administrator

- Annual procurement plans

- Accounting system of documents of the administrator under the Law of Ukraine "On Access to Public Information"

- $\quad$ Register (list) of the open datasets

- Lists of administrative services, information cards of the administrative services and application forms required for applying for the provision of the administrative services

- Information on treasury bills for payment for administrative services

- Administrative data collected (processed) by the information administrator

- Legal acts to be disclosed pursuant to the Law of Ukraine "On Access to Public Information"

- Financial statements of the economic entities in the public sector of the economy, which are within the scope of management of the information administrator

- Legal framework of Ukraine (Database "Legislation of Ukraine”)

- Information on consideration of the agenda of Verkhovna Rada of Ukraine

- Information on the bills registered in Verkhovna Rada of Ukraine

To ensure access to public information, it is also encouraged to provide access to those data sets that are not included in the list specified by the Regulation, unless otherwise provided by the Law of Ukraine "On Access to Public Information". This especially applies to information of considerable public interest (high frequency of questioning, reflecting results of public opinion polls, etc.). Since any information about the activities of Parliament is of considerable public interest, all the data 
published on Parliament's website shall also be published as Open Data. To enable this, a separate "Open Data" section should be created on the website of the Verkhovna Rada of Ukraine.

The "Open data by default" principle should also be provided during the design and creation of new information systems on Parliament's website".

In April 2016 Open data Portal Ukrainian Verkhovna Rada [16] was presented. It consisted of more than 100 datasets about Ukrainian Parliament and open API. There is mostly structured, updated information on plenary session meetings, MPs, voting records, legislation and drafts of laws. This information is in open data format. Meanwhile, there is also financial information and information about staff not in machine readable format. There is also questions about sustainability and support of other datasets that has automatic updating.

There is no chief open data officer for sustaining the portal, no access to other databases despite of legislation, plenary meetings, MPs (financial information, information about committees etc.), lack of technical competencies of IT-staff in the parliament and, the main, understanding of importance of open legislative data in the Ukrainian parliament. No inner regulations in Parliaments makes this question out of the agenda.

As a project manager of Open Data Parliament Portal development, now I see the main challenges and obstacles on the path of open legislative data development. That is why I have some suggestion about that.

\section{How to open legislative data}

Open legislative data need political will and technical capacity, as well as the users of these data. It means - ecosystem of open legislative data.

Political will mean that the open data as a principle is officially defined (order, resolution etc). There should be the chief open data officer (responsible for open data in Parliament) and direct finance for open data (salary, good equipment, good and sustainable data bases), competences and motivation of IT-department as well as strong, data-savvy and motivated PMO.

It also good than besides political will and finance there is also the legislative framework for open data (in laws or other normative documents that is obliged for fulfillment by every state body).

The crucial thing to do before starting open legislative data process is to have deep assessment for getting awareness on state of data bases, equipment, competencies of IT-staff etc. The World Bank's Open Government Data Working Group developed the Open Data Readiness Assessment (ODRA) [17] methodological tool. It can be used to "conduct an action-oriented assessment of the readiness of a government or individual agency to evaluate, design and implement an Open Data initiative".

The second question is what kind of data have to be open primary. This is a question that parliament should address to stakeholders. There should be a constant communication with PMOs, think tanks etc about what kind of data, in which exact format and updating regularity open data should be published by the parliament. 
Typically, parliaments publish such kind of data as:

1) voting records (one of the most important dataset as it is used to discover real policy making and real political interests). Ukrainian product of Civil network OPORA for surfing voting records in user friendly interface Rada4you [18]

2) speeches (parliament speaks: during plenary sessions, hearings, government hours etc. there are millions of words are spoken). Ukrainian instrument of Civil network OPORA for surfing MP's speeches Radastenograma [19]

3) information about MPs and their assistants (background, work in and outside the parliament, declarations, conflict of interests, requests, drafts etc Ukrainian product for getting information on MPs and their attendance). Ukrainian products of Civil network OPORA and Civil Movement Chesno [20]

4) bills (legislation) - the main information is legislation

5) drafts of laws and its passage in the parliament. Ukrainian application for IOS, developed by Civil Movement Chesno ZAKONOPROEKT [21]

6) information about committees (attendance, meetings, hearings, voting, conclusions, drafts, protocols, passing drafts of laws there).

7) financial information (about MP, offices, assistants, administrative costs).

8) e-petitions (what citizens want from parliament, MPs).

These are the main datasets that should be primarily open by the parliament. But what kind of open data format it should be published? According to World e-parliament report 2016 [22], 80\% of documents in parliaments all around the world are published in PDF format which is not the format that can call easily to be read by machine.

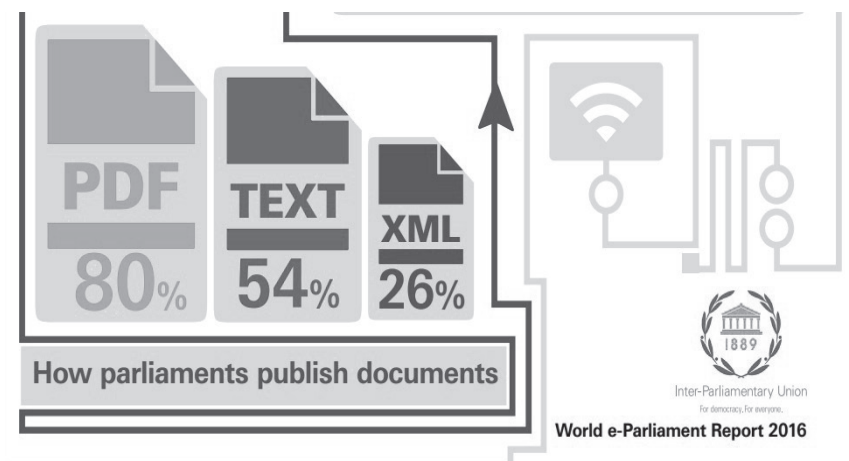

Figure 2: Formats in which parliaments publish its documentsaccording to "World e-Parliament Report", 2016 
Tim Berners-Lee, the inventor of the Web and Linked Data initiator [23], suggested a 5-star deployment scheme for Open Data.

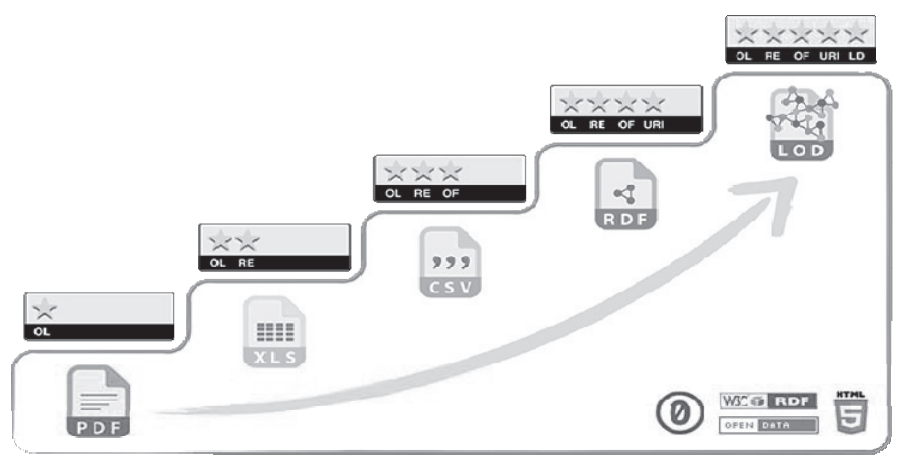

Figure 3: Types of open data according to Tim Berners-Lee's classification

As we can see, PDF - is the lowest level of open data format. It is better to use Extensible Markup Language (XML), JavaScript Object Notation (JSON) and comma-separated values (CSV) formats for open legislative data.

Good structure, metadata and description for datasets are as important as data itself. All datasets should have open application programming interface (API) for searching and getting exact data.

The question about the platform to use for datastoring, repositoring and publishing information is also important. Ukrainian open parliament portal is on Drupal based Knowledge Archive Network (DKAN). It is open source platform, as well as Comprehensive Knowledge Archive Network CKAN, which is used by UK parliament. GITHUB - web-based Git repository hosting service [24]. There are also other platforms, but these are more popular and open source platforms.

\section{References}

[1] The International Open Data Charter, http://opendatacharter.net/wp-content/uploads/2015/10/ opendatacharter-charter_F.pdf (as per December 31st, 2016).

[2] Open Data Barometer, http://opendatabarometer.org/ (as per December 31st, 2016).

[3] Global Open Data Index, http://index.okfn.org/ (as per December 31st, 2016).

[4] Local Open Data Census, http://census.okfn.org/en/latest/\#cities (as per December 31st, 2016).

[5] Parliament https://en.wikipedia.org/wiki/Parliament (as per December 31st, 2016).

[6] Nadiia Virna, Grygorij Sorochan, Open Parliament Data: from a trend to a necessity, https://www.oporaua.org/en/news/42391-open-parliament-data-from-a-trend-to-a-necessity, 2016 (as per December 31st, 2016).

[7] Open data portal of British Parliament, http://www.data.parliament.uk/ (as per December 31st, 2016). 
[8] Open data portal of French Senate, http://data.senat.fr/ (as per December 31st, 2016).

[9] Open data portal of Sweden Parliament, http://data.riksdagen.se/In-English/ (as per December 31st, 2016).

[10] Open data portal of Norwegian Parliament, http://data.stortinget.no/ (as per December 31st, 2016).

[11] European Union Open Data Portal, https://data.europa.eu/euodp/en/data/publisher/ep (as per December 31st, 2016).

[12] La Fabrique de la Loi, http://www.lafabriquedelaloi.fr/ (as per December 31st, 2016).

[13] World e-parliament report 2016, http://www.ipu.org/pdf/publications/eparl16-en.pdf (as per December 31st, 2016).

[14] Declaration on Parliamentary Openness, https://www.openingparliament.org/ (as per December 31st, 2016).

[15] The National Action Plan, http://www.opengovpartnership.org/blog/open-governmentpartnership/2016/02/08/announcing-open-parliament-action-plan-ukraine (as per December 31 st, 2016).

[16] Open data portal of Ukrainian Parliament, http://opendata.rada.gov.ua/ (as per December 31st, 2016).

[17] Open Data Readiness Assessment, http://opendatatoolkit.worldbank.org/en/odra.html (as per December 31st, 2016).

[18] Rada4you, https://rada4you.org/ (as per December 31st, 2016).

[19] Radastenograma, http://radastenograma.oporaua.org/ (as per December 31st, 2016).

[20] Deputaty, https://rada.oporaua.org/deputaty/deputati, http://www.chesno.org/deputies/ (as per December 31st, 2016).

[21] ZAKONOPROEKT, https://itunes.apple.com/WebObjects/MZStore.woa/wa/viewSoftware?id $=1093063414 \& \mathrm{mt}=8$ (as per December 31st, 2016).

[22] World e-parliament report 2016, http://www.ipu.org/pdf/publications/eparl16-en.pdf (as per December 31st, 2016).

[23] Web and Linked Data initiator, http://5stardata.info/ (as per December 31st, 2016).

[24] Github, https://github.com/SenatoDellaRepubblica/AkomaNtosoBulkData (as per December 31st, 2016). 